Review

\title{
Trends in Surgical and Beauty Masks for a Cleaner Environment
}

\author{
Pierfrancesco Morganti ${ }^{1,2, *}$, Vladimir E. Yudin ${ }^{3}$, Gianluca Morganti ${ }^{4}$ and \\ Maria-Beatrice Coltelli ${ }^{5, * \text { (iD }}$ \\ 1 Academy of History of Health Care Art, 00186 Rome, Italy \\ 2 Department of Dermatology, China Medical University, Shenyang 110122, China \\ 3 Institute Macromolecular Compounds, University of St Petersburg, Russian Academy of Science, \\ 199034 St. Petersburg, Russia; yudin@hq.maceo.ru \\ 4 ISCD NanoScience Center, 00165 Rome, Italy; gianluca.morganti@iscd.it \\ 5 Department of Civil and Industrial Engineering, University of Pisa, 56126 Pisa, Italy \\ * Correspondence: pierfrancesco.morganti@iscd.it (P.M.); maria.beatrice.coltelli@unipi.it (M.-B.C.)
}

Received: 21 July 2020; Accepted: 17 August 2020; Published: 31 August 2020

\begin{abstract}
The surgical face mask (SFM) is a sheet medical device covering the mouth, nose and chin to protect the medical staff from the spread of respiratory droplets produced by the infective coughing or sneezing of hospitalized patients. On the other hand the beauty face mask (BFM) has been made by the same sheet but with a different aim - to protect the skin from pollution, acting as a hydrating and rejuvenation agent. Currently, both masks are made principally by non-biodegradable tissues, utilized to avoid the increasing great pollution invading our planet. Due to the diffusion of the current COVID-19 infection rate and the increasing consumption of skin care and beauty products, the waste of these masks, made principally by petrol-derived polymers, is creating further intolerable waste-invaded land and oceans. After an introduction to the aims, differences and market of the various masks, their productive means and ingredients are reported. These news are believed necessary to give the reader the working knowledge of these products, in the context of the bioeconomy, to better understand the innovative tissues proposed and realized by the biobased and biodegradable polymers. Thus, the possibility of producing biodegradable SFMs and BFMs, characterized for their effective antimicrobial and skin repairing activities or hydrating and antiaging activity, respectively. These innovative smart and biodegradable masks are requested from the majority of consumers oriented towards a future green environment. Giving this new sense of direction to their production and consumption, it will be possible to reduce the current waste, ranging worldwide at about 2 billion tons per year.
\end{abstract}

Keywords: biodegradable polymers; non-woven tissues; electrospinning; biopolyesters; polysaccharides; chitin nanofibrils; lignin; surgical and beauty masks

\section{Introduction}

Surgical face masks (SFMs) and beauty face masks (BFMs) are products made by specialized tissues that have the basic aim of protecting the face from the aggression of microorganisms and pollutants, respectively [1,2].

The global market of face masks may be shared out in two different categories of sheets, used respectively for medical or cosmetic purposes. SFM is a medical device covering the mouth, nose and chin with the purpose of limiting the transition of an infective agent between the hospital staff and the patient [1]. It is a means that prevents the spread of respiratory droplet produced by coughing or sneezing and protects health care workers and patients from microorganism infection [1]. 
BFM would catch dirt and pollution, providing the contemporary fast deep hydration, replenishment and rejuvenation of the skin, with the aim to ameliorate its general health and appearance [2].

Both the masks are currently produced by layers made generally by fossil-based spun-bond and melt-blown non-woven tissues, or by emerging techniques such as electrospinning or texturized film extrusion technologies [3]. They are therefore tissue-engineered products, emerging from the convergence of different health care disciplines such as biological science, nanotechnology, material science, information technology, etc. Various research studies and the advancements in nanobiotechnology have led to a de novo design and the fabrication of innovative nanoengineered materials and biomaterials [4,5]. Thus, by petrol-derived chemistry, many new plastic polymers have been synthesized to produce tissues. Natural polymers such as polysaccharide and biobased polymers synthesized from renewable monomers, such as poly(lactic acid) (PLA), seem to be a valid alternative to these fossil based versions, as well as polymers obtained by microorganisms like poly(hydroxyalcanoate) (PHA). Particularly the natural polymers have shown to be useful for producing functional tissues able to mimic the function of the native extracellular matrix (ECM) [5]. However, all the described classes of polymers are useful in producing tissues, characterized by their different functionalities, biocompatibility and biodegradability [6].

Fossil-derived polymers possess a consolidated processing capability and a low cost, but are not biodegradable. They are characterized by their accumulation and persistence in the environment [7]. On the other hand, the mentioned natural-derived polymers show performances and industrial possibility to be processed at a lower maturity level, but they are totally biodegraded to safe ingredients. However, polymers and active ingredients used to make SFMs and BFMs are not the same, because of the different functionalities and activities they should provide to the skin and body.

However, in our opinion, it would be necessary to produce all these masks by skin-friendly and ecofriendly raw materials, to protect human health and the environment.

SFMs and BFMs are described in the next sections considering their current prevalent structure and composition and their present and future market. These data can be relevant to give indications to readers about the future perspectives of applied research in these fields, taking into account the actual growth of the bioeconomy. Then, the environmental concern linked to both masks is presented in successive section and finally the use of different biopolymers to replace fossil-based materials is discussed in Section 5. The present review wants to give to the reader some general information and views on the use of biobased materials in these applications.

\section{Surgical Face Mask Activity and Market}

Surgical face masks (SFM) are made principally for medical purposes to protect doctors and health care workers from infections caused by microorganisms. Their production and use, notably increased from the year 2019 due to the diffusion of COVID-19, that involved until today, 20,260,000 affected people, provoking 740,000 deaths [8]. These masks, in fact, acting as a barrier between the wearer and contaminants, are used massively worldwide to reduce the contact with highly infective microorganisms and viruses not only between doctors and health care workers, but also among people worldwide. How are these masks made?

Produced prevalently by non-woven tissues, they are generically made up of three or four fine layers, able to filter from $85 \%$ to $99 \%$ of materials, having a dimension higher than 1 micron in size [3-5]. The innermost layer absorbs moisture (breath, cough, etc.), the middle layer acts as a filter for infection agents and nanoparticles, while the outer layer is repellent for liquids (water, blood, etc.) [9]. These tissues are prevalently manufactured by polypropylene (PP) to obtain a non-woven fabric or textured film, respectively, characterized by the different dimensions of their fibers and interfibrillar spaces.

Among all the petrol-derived polymers (i.e., polyethylene, polyethylene terephthalate, poly-acrylonitrile, etc.) used as materials to produce the various disposable masks in the market, polypropylene (PP) dominates as the second-highest revenue, for its low cost and simplicity in 
processing and usage [10-12]. The advantages of non-woven fabrics over woven fabrics (knitted) are their higher air permeability, higher bacterial filtration efficiency and low manufacturing cost. However, all the SFMs, while highly protective against microbiome, fungi and viruses, are often not comfortable for wearers, especially in the mouth and nose areas where the sweat vapor, transformed into liquid droplets, causes skin irritation. At this purpose and for solving this problem, it was proposed, to cover the PP fibers by adsorbent polymers, such as poly (vinyl alcohol) (PVA) [13]. By this method, the PP fibers increase their hydrophilicity so that sweat, absorbed into the fiber, is no more transformed into an irritative liquid.

To assure their quality, the surgical disposable masks, as medical devices, have to follow the official standards according to the rules of the Ministry of Health in different countries, such as Europe (EU) [14] and the World Health Organization (WHO) [15].

These SFMs, therefore, are registered products which, having to fulfill particular requirements, report on the label some imposed specifications, such as their ingredients and modality of use, in order to provide sufficient data for the surgical staff, health care workers and other consumers. These masks, in fact, must be controlled for their bacterial barrier and filtration efficiency, breathing capacity, splashing characteristics and flammability resistance, according to the Health Ministry rules. Thus, disposable masks, made by three to four layers and currently used for the COVID-19 pandemia (Figure 1), are packaged and sterilized, so that their use may prevent the spread of infection better than reusable, non-woven or knitted ones [9,11,12]. Just to have an idea of the global market insights, the protective mask market value of around USD 1 billion in 2019, is supposed to surpass USD 2.8 billion by 2026 [16-18].

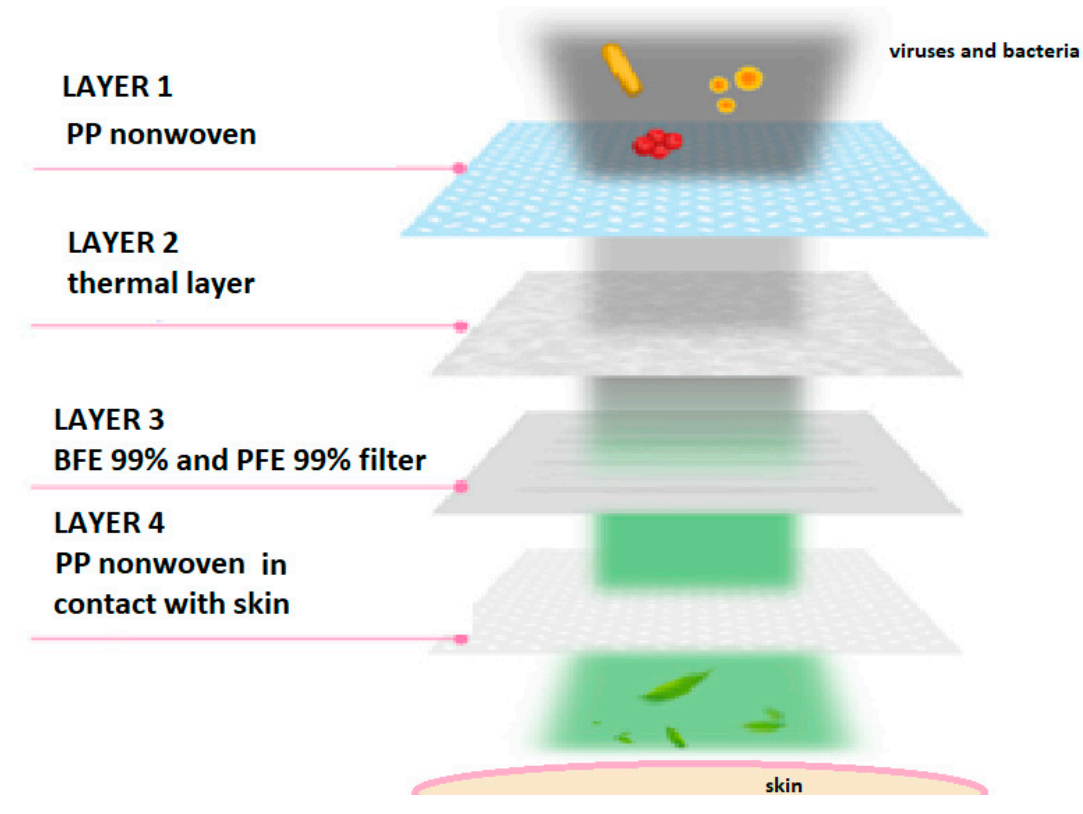

Figure 1. Surgical face masks layers.

On the other hand, the reusable surgical face masks have a reduced filtration power and protection efficiency, due to their frequent washing cycles. In addition, the repeated laundering causes a further waste of energy, generating also more wastewater in the environment. As previously reported non-woven masks, made by two/three layers of tissues and principally used in hospitals, are manufactured worldwide by PP, as the most used polymer (Figure 1). Different are the designs that can be followed. In the reported example of Figure 1, composed of four-layered tissues, the first non-woven layer avoids the ingress of dust-air, the fourth layer in contact with skin has a protective function, while the second and third core layers, have a bacterial filtration capacity of $99 \%$ and a particulate filtration effectiveness of $99 \%$, usually obtained by melt blown non-woven fabrics. 
The surgical mask market is continually growing due to the increased number of people driving worldwide its personal usage, because of the growing number of COVID-19 affected patients [8,11,12]. These masks, in fact, are used by personal health care personnel at the workplace and by the general public too as protective means against virus outbreaks, air indoor and outdoor' air pollution, vehicle and industrial facility gas emissions, all causes of allergies and cardiovascular, respiratory and other diseases [19].

The market has been categorized by different companies not only in terms of the economic turnover, size, trends and future challenges of the masks, but also for the raw materials (cotton, polypropylene, paper and others) and the different layers used for their production [12-14]. These research studies cover woven and non-woven masks, protective for dust or microorganisms, respectively. Their use, in fact, is also grown because of the general needs of protection from pollution and diseases, connected worldwide to the increasing aging population [14-19]. In conclusion by Global Newswire, the global market has been estimated at about USD 4.5 billion with an expected compound annual growth rate (CAGR) of 24\% by 2026 [10], while Technavio [15] reports an incremental growth of USD 2.41 billion with an annual CAGR of over 8\% from 2019 to 2024 for the SFMs (Figure 2a).

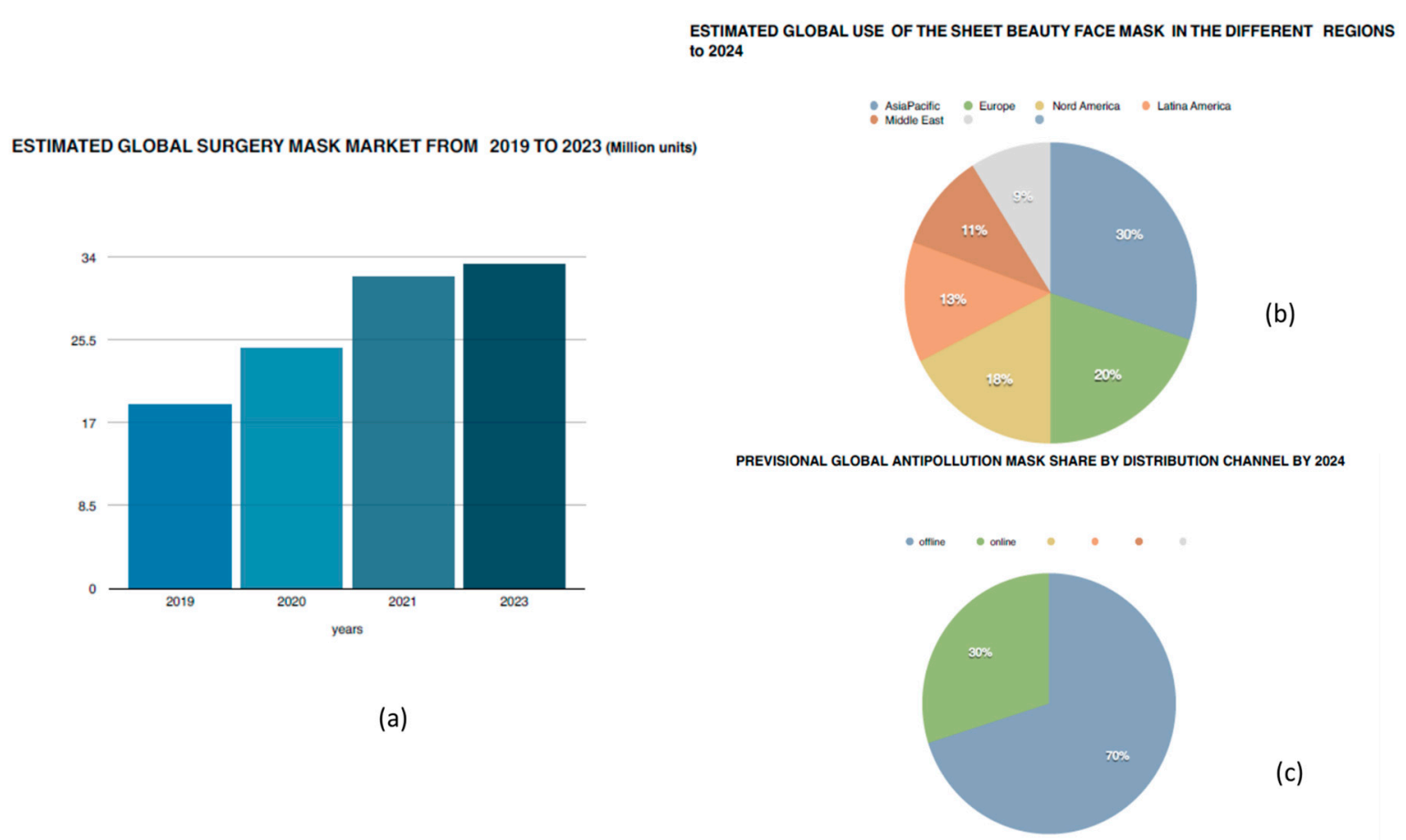

Figure 2. (a) The incremental growth of surgical masks [20]. (b) Global surgical masks market share by region in 2018. (c) Disposable surgery face masks by application: industrial and personal (by courtesy of GranViewResearch [18]).

In terms of countries (Figure 2b), Asia Pacific was the most attractive region in the disposable face masks market in 2019 with a share of $33.3 \%$, due to the increasing population, growing manufacturing and health care facilities in most notably countries such as China and India. North America and the EU are expected to be other major markets, while the Middle East, Africa and South America are expected to witness a slow growth.

The distribution channel by region was segmented into offline shopping, resulting in the largest category in 2019 with a market share of $80.7 \%$, while online shopping was used more in the emerging markets [18]. By application it is possible to distinguish two production categories-industrial, the main category in 2019, and personal (Figure 2c) [16-18]. 


\section{Beauty Face Masks (BFMs) Activity and Market}

Differently from surgical masks, which have a protective role against microorganisms, beauty masks should mobilize the endogenous skin defense and the cellular detoxification systems, as previously reported [2,21,22]. It is supposed, in fact, that beauty masks could increase the skin's self-defense, becoming more effective and proactive to safeguard the skin ecosystems. As a consequence, BFMs could promote the breathing of the skin and normalize the physiological cell turnover, thus preventing the premature aging phenomena (Figure 3). Obviously the selected active ingredients, which can be used to modify the non-woven fibers and the electrospun polymers, have to be different from those used for the SFMs.

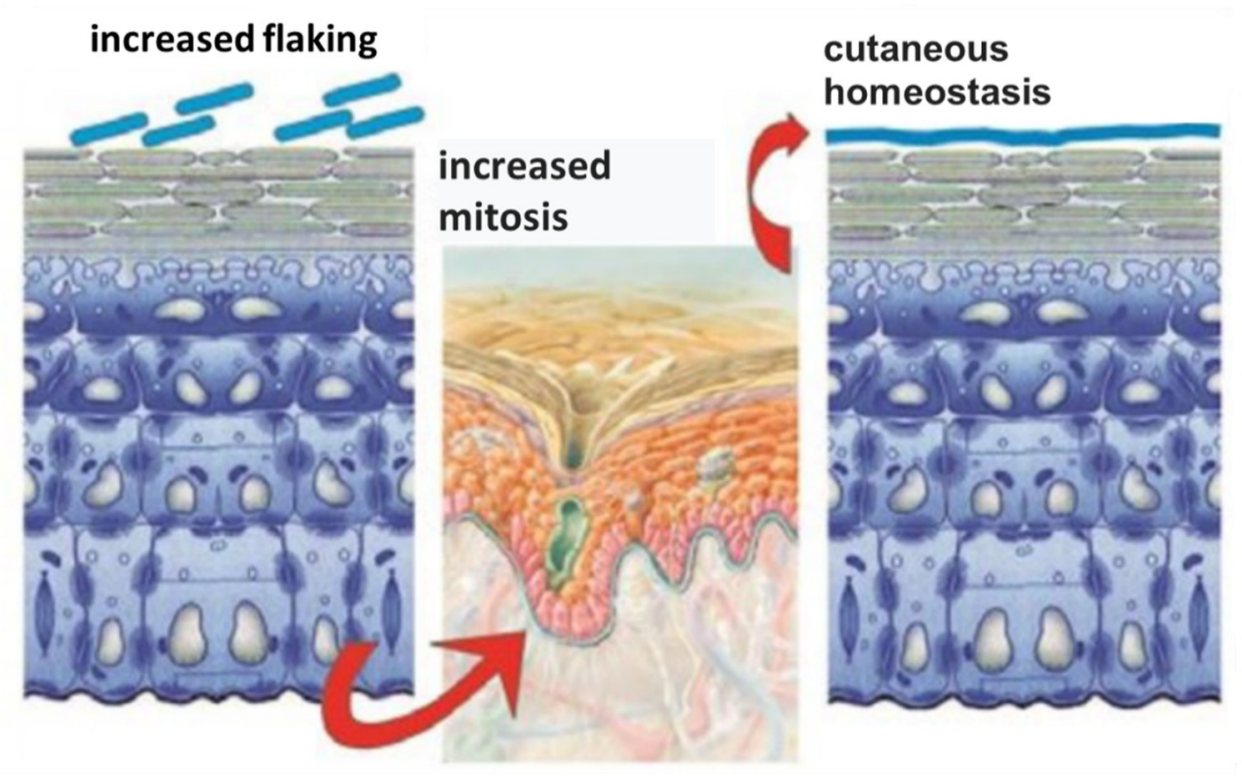

Figure 3. The normal skin turnover.

However BFMs, according to their assigned effectiveness, are enclosed into a particular category of the cosmetic global market. Thus for this niche of market, which is highly fragmented and competitive, the players are engaging a variety of strategies to produce innovative products.

As a consequence, it is possible to recognize seven basic types of face masks with different claiming benefits: clay or mud mask, cream mask, gel mask, peel-off mask, charcoal mask, sleep mask and sheet mask $[23,24]$. All these specialized cosmetics are principally used to supplement the daily skin care regime routine, ameliorating the skin hydration and the body' general health and appearance $[18,21,22]$.

At this purpose, $76 \%$ of Chinese women aged $20-49$ are using these masks for hydrating the skin, followed by $58 \%$ of consumers that are looking for skin whitening and $47 \%$ for pore refining. Differently, among the US consumers, $29 \%$ are looking to treat acne or blemishes and $27 \%$ to slow down the signs of aging, such as fine lines and wrinkles [23,24].

In conclusion, consumers worldwide, suffering from uncertainty also for the recent COVID-19 diffusion, have the need to feel safe more than ever. Thus, they are looking for innovative and effective cosmetic products and sheet masks able to ameliorate their appearance and body health, slowing down the stress condition and matching their own skin type and life-style. As a consequence, self-esteem is improved with positive effects on several aspects of the self-image [25].

Regarding the market and according to Statista data, the value of sheet facial masks sheared USD 282.8 million in 2018, with an estimated increase to USD 551.3 million in 2026, as part of the global cosmetic market with a revenue of USD 489 billion in 2018 [23]. Differently, Allied Market Research evaluated the same market size at USD 206 million in 2018 with an estimated USD 392.1 million by 2026 with a CAGR of $8.8 \%$ during the forecast period of 2019-2026 [24]. 
However, it seems well established that the growth of sheet face masks has been influenced from the increased spending on cosmetic and personal care products, coupled with rising living standards of the consumer's majority. Moreover, these sheet-cosmetics are considered beneficial for their hydrating and antiaging effectiveness, as well as for the possibility to be used while traveling or even doing household chores [23]. How these masks are made? These cosmetics are generally made of cotton fabric often mixed with synthetic polyesters, biocellulose and other polymers infused with cosmetic active ingredients, to provide long lasting effects, compared to traditional topical serum and hydrogels. They are preferred by consumers because they ready to use and considered to be made of natural ingredients and by new technologies, skin-friendly and ecofriendly. "The increased awareness towards sustainability and environment footprint, in fact, are largely influencing purchase decision of consumers" [24]. About the regions involved and according to Mintel research data, Asia Pacific dominated the worldwide beauty sheet market and accounted for $76 \%$ with a CAGR of $8.5 \%$ of all global masks launched in 2016, owing to high product consumption in countries such as South Korea and China $[16,17]$ These countries follow the intensive skincare routines in which the application of this sheet mask represents an important step to hydrate the skin quickly, making it soft and glow in the shortest time [18]. Thus, as previously reported, Asia Pacific accounted for most of the global sheet market (76\%), followed by the EU (16\%) and USA ( $8 \%$; Figure 2b) [26]. However, the more innovative market results in Asia Pacific with the most launches coming from the North Asian region, with China accounting for $28 \%$ of all the global sheet mask' introductions, followed by Taiwan $12 \%$, South Korea 10\%, Hong Kong 7\% and Japan 6\%. About the size, China, Japan and South Korea are currently the world's largest facial care market estimated to reach a retail market value of USD 15.8 billion, USD13.5 billion and USD 6.6 billion respectively [26], also because a sheet mask is now a frequent feature in many consumers' skincare routine. At this purpose, $75 \%$ of Chinese consumers use masks in the evening before sleeping, while $68 \%$ use them in the morning and during the day also. Additionally, $53 \%$ agree that facial beauty masks are the best first-aid skincare products so that $40 \%$ of women aged 30-39 used them in the last 12 months [27]. Actually in western countries these masks are gaining in popularity as a regular beauty treatment, also they were used prevalently in an evening routine in the last 12 months: from 12\% of consumers in the UK, 10\% in France, 10\% in Germany, 8\% in Spain and $8 \%$ in USA. However, North America is projected to exhibit exponential growth throughout 2026, registering the highest $11 \%$ CAGR with the supermarket/hyper markets segment dominating and the E-commerce segment estimated to grow at a CAGR of $11.7 \%$ [24].

In conclusion, consumers are more concerned about materials and active ingredients used in the manufacturing and packaging of skin care products and beauty face masks, having special attention to skin health and to the environment preservation [27]. They, in fact, have etched in their minds the concept of zero waste, waterless and safeness. Thus, the adoption of innovative and smart technologies and natural ingredients is expected to propel the revenue growth of the overall beauty face mask market, also because this specific cosmetic product is considered multifunctional, with better performances, easy to use and able to give new benefits to the skin's health [21,22,27].

\section{Surgery and Beauty Face Masks: The Environment Problem}

Although there are many natural polymers present in the market, the majority of surgery and beauty masks and their packaging are made of fossil-derived polymers, the recycling of which is difficult, being not separately collected and sorted [28,29]. Unfortunately they are made of non-biodegradable materials, contributing to worsening the worldwide plastic waste pollution (Figure 4) [30,31] and at the same time increasing greenhouse gas emissions that, from around 0.8 billion tons in 2019, will probably be 2.8 billion tons by 2050 [32]. Moreover, it is not to be forgotten the increasing global production of plastics that, coming from 1.5 million metric tons in 1950, increased to 348 billion metric tons in 2018 with a consumption per capita of $45 \mathrm{~kg}, 40 \%$ of which is disposed as waste to landfills [33,34]. 


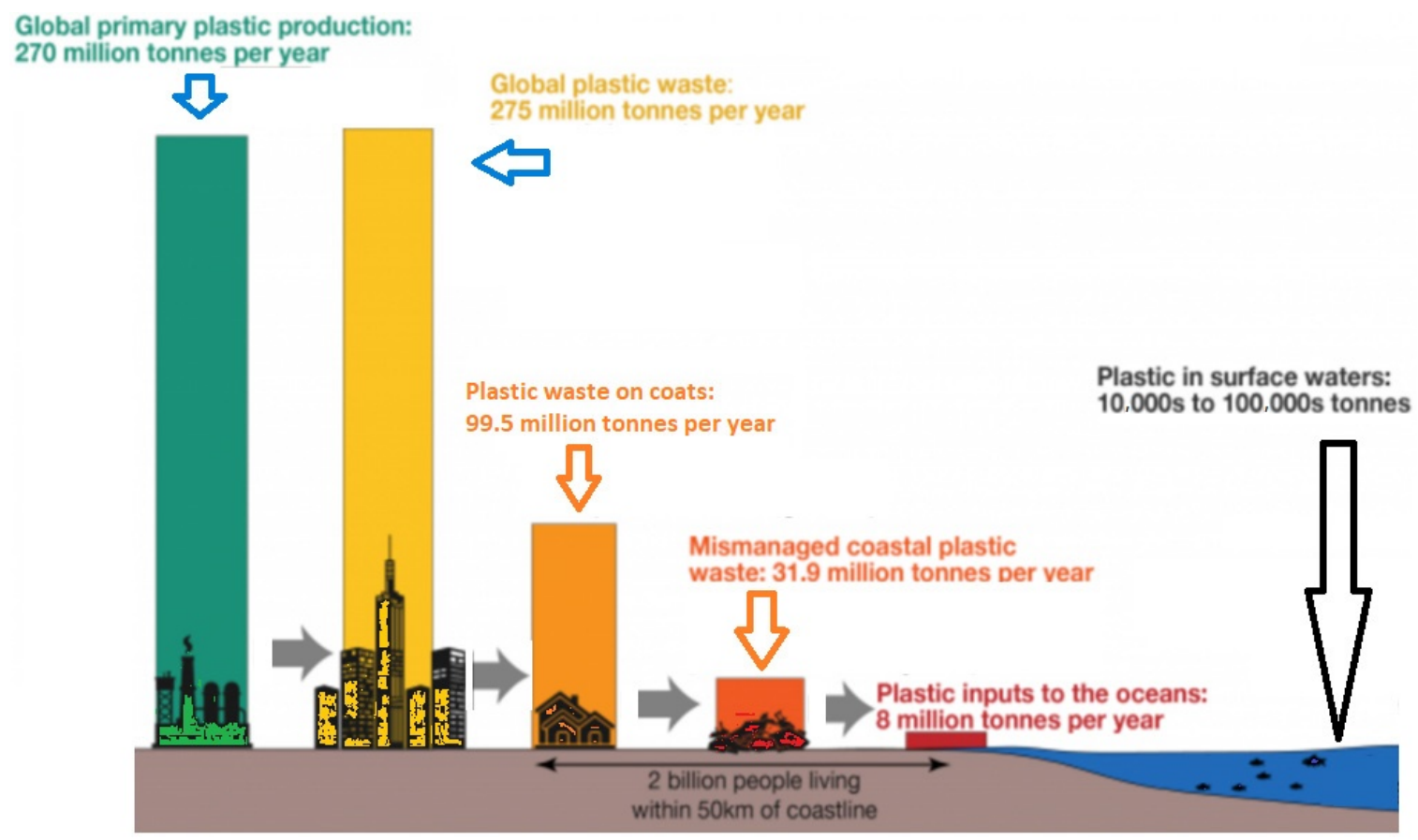

Figure 4. The pathway by which plastic enters the world's oceans: estimates of global plastics entering the oceans from land-based sources in 2010 (based on data from Jambeck et al. [30]).

Therefore, global waste with a value projected to increase to USD 530 billion in 2025 will generate 2 billion tons/year of materials, composed of $40 \%$ of consumer products. Around $13 \%$ of these materials is represented by plastics, $9 \%$ by textiles and $15 \%$ by food, while the majority of this waste is due to the urbanization population growth and the worldwide economy development [32]. Regarding the regions, $50 \%$ and $38 \%$ of this waste is produced in Asia Pacific and Europe respectively. This high increase, in fact, is directly connected to the wellness economy, which grew annually by $6.4 \%$ from 2015 to 2017 , nearly twice as fast as the economic growth (3.6\%), increasing to USD 4.5 trillion [33]. Just as an example, it has been calculated that only the worldwide personal care and beauty waste increased to USD 1082 billion in 2017 [33], producing every year more than 120 billion units of packaging, $60 \%$ of which are not biodegradable. Unfortunately this waste material is partially recycled while the majority of them are mainly incinerated. Thus, there is a necessity to change the linear economy into a circular economy $[34,35]$ by a more environmentally-friendly approach based on the use of recycled or recyclable, textiles, packaging, surgical and beauty masks. This is the aim of the New Plastic economy Commitment organized by the Ellen MacArthur Foundation in collaboration with the United States Environment Program, which includes also companies representing $20 \%$ of the global plastic packaging producers. Therefore, it is time to produce zero waste, drastically reducing the current consumption of non biodegradable plastic, the waste of which is entering in the food chains with dangerous effects on flora, fauna and humans. Estimates suggest, in fact, that annually more than 100,000 marine mammals and turtles and over one million sea birds are killed by marine plastic, which, broken down into 5.25 trillion of micro-pieces, adsorb toxins, resulting in poisoning of animals that accidentally ingest it [35].

Currently, as previously reported, the problem of plastic waste is further increased by the COVID-19 problem due to the increased use of protective and sanitizing products. A growing number of countries, in fact, are encouraging citizens to wear protective equipment in public to cover the face by masks and protecting the hands by gloves, which have to be cleaned frequently by sanitizing gels, which are unfortunately packed in fossil plastic [34,35]. As a consequence consumers have embraced the clean and health concept, changing their purchase habits. They buy not only more masks, gloves, cleaning solutions and gels, but also more colored cosmetics, rethinking nail and eye care at home and outside, due to the closure of the beauty salons also [36]. Consumers, in fact, wearing masks, 
try to look more attractive, evidencing their eyes and nails by the use of more colored make-up [36]. Moreover the anxiety, shifting focus to health and safety, encourages consumers to seek protection against outdoor and indoor pollution also, for trying to go back to a more sustainable lifestyle [37]. Thus, the level of air pollutants, which are increasing worldwide, may be considered the real cause of many health-related problems with risks of microbial and viruses' infections, such as the COVID-19 pandemic, certainly connected also with a wrong way of consumption. In conclusion beauty standards are evolving and customers are appreciating who they are, thus looking for a different way of living, more respectful of both their personal health and the planet's environment.

Consequently, "conscious consumers are seeking out to make positive decisions about what they could buy, looking for a solution to the negative impact environment and consumerism are having on the world" [38]. Moreover, they are looking for high quality and high performing cosmetic and healthy products that, made by natural ingredients and sustainable and transparent production, could be able to effectively shift their activities from aging to longevity [39].

Therefore, surgical and beauty face masks, designed and realized by biodegradable natural materials, appear to become an important part of future products requested and purchased from consumers.

\section{Innovative Renewable and Biodegradable Polymers for Non-Woven Tissues}

As previously reported, the world generates around 2 billion tons per year of municipal waste, expected to grow to 3.4 billion tons by 2050. In the future the recycling of waste will become mandatory as a pivotal methodology of its management. Thus, also a great part of organic waste would be recycled for obtaining natural polymers such as starch, cellulose, lignin and chitin to be used for making biodegradable non-woven tissues and films [40], suitable to produce innovative SFMs and BFMs. These biobased polymers are generally processed by standard non-woven industries and by high throughput manufacturing techniques (melt blown, spun bond and casting) [41].

The electrospinning technology is the most used in cosmetic and regenerative medicine because it may easily create three dimensional fibrous scaffolds, closely imitating the nano-to micro-mesh work of the native extracellular matrix (ECM) [6,42-45]. By this technology it seems possible to produce scaffolds mimicking the structure and function of the ECM, necessary to allow the normal function and interaction of the skin cells [32]. Moreover, it is possible to obtain polymeric nanofibers of thin size tissues, characterized for their higher effectiveness because of their high surface to volume ratio and the many interfibrillar nano-dimensioned holes catching the air nanoparticulate. The use of this technique could be an alternative to the traditional production of spun-bonded or melt blown tissues, often used as an external or internal layer of the SFMs. However as previously reported, the internal third layer may be obtained generally by the casting technique, by which it is possible to obtain shorter micrometric fibers with less interfibrillar holes, so that both nanoparticles and microorganisms do not have the possibility to pass through (Figure 5).

In any way, the electrospinning is also a very simple technique because it is composed of a unit made by a syringe containing the liquid material consisting of a polymer solution or suspension to be electrospun; a pump that controls the liquid flow rate; a high voltage current supplier; a metal plate collector and a spinneret. Naturally the property of the liquid material and the process parameters are crucial for the physical, morphological and biomechanical performance of the electrospun fibers, which may be characterized and varied for their porosity, tunable pore size and high surface-to-volume ratio [43-45]. Thus, it is possible to produce different non-woven tissues designed for different purposes and applications. Many properties of the biomaterials used and the tissue-scaffolds realized, such as porosity, mechanical properties and degradation behavior, in fact, play a pivotal role for their activity as skin regenerating carriers.

The use of biopolymers to produce BFMs and SFMs, therefore, can be promising and useful as well as the electrospinning technique. In fact, only some biobased polyesters, like PLA and its blends, can be extruded into fibers via melt blowing or wet laid processes, while other thermal resistant polymers 
can undergo degradation during these processes. In general, it has been a considerable challenge to convert polyhydroxyalkanoates (PHA) copolymers as well as other biodegradable polymers into useful forms by conventional melt methods because, after the melting and cooling down processes, they remain substantially tacky. Consequently, there is a need for alternative fiber production methods. Often, the only possible routes for making biopolymer fibers are represented by productive processes made at room temperature, thus involving polymer solutions, like electrospinning with the necessity to use biodegradable and ecosustainable solvents. However, to obtain nanostructured tissues the method of election seems to be the electrospinning technique by the use of polymers water-soluble or suspendible, like the polysaccharides-based ones.

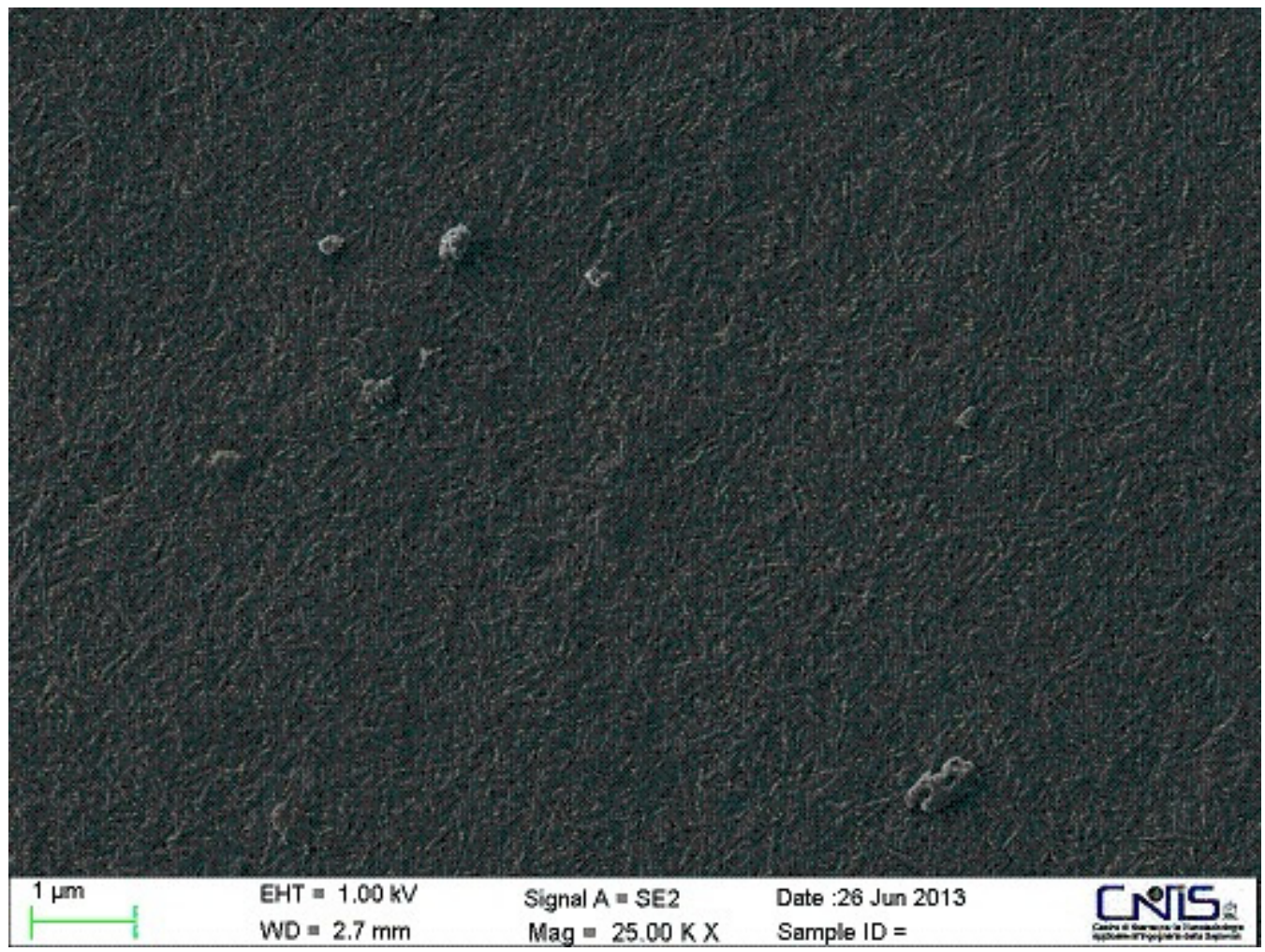

Figure 5. Fibers dimension and interfibrillar boles of a chitin nanofibrils (CN)-film at SEM.

For producing SFMs or BFMs several biobased materials can be considered. The class of polysaccharides (Figure 6) consists of very hydrophilic polymers, able to retain water when at the wet state, with the possibility to transfer it to the skin, when in contact with its surface. Hence their use in beauty masks could be useful. Some of these polysaccharides, in fact, may be soluble in water like pullulan or insoluble but easily suspendible, such as starch, cellulose or chitin nanofibrils, obtained as a polymer covered by positive charges. However, all these polymers' results are promising for their possibility to be electrospun in water [43-46]. On the other hand, they are not highly thermally resistant, so their processing by conventional methodologies can be quite difficult.

On the contrary the less hydrophilic biopolyesters, such as PLA and PHA, can easily undergo by conventional processing methodologies to produce non-woven tissues. Thus, PLA, obtained from polymerization of lactic acid, and PHA, obtained from microorganisms, are materials potentially suitable for making SFMs and BFMs, being fully biobased and biodegradable polymers as well as the commercial biopolyesters poly (caprolactone) (PCL), poly(Butylene succinate (PBS) and poly(butylene adipate-co-terephthalate) (PBAT) obtained partially by non renewable sources. However, the actual industrial trends are oriented to obtain these polymers from renewable sources only, for having in next years more commercially available fully biobased biopolyesters. 

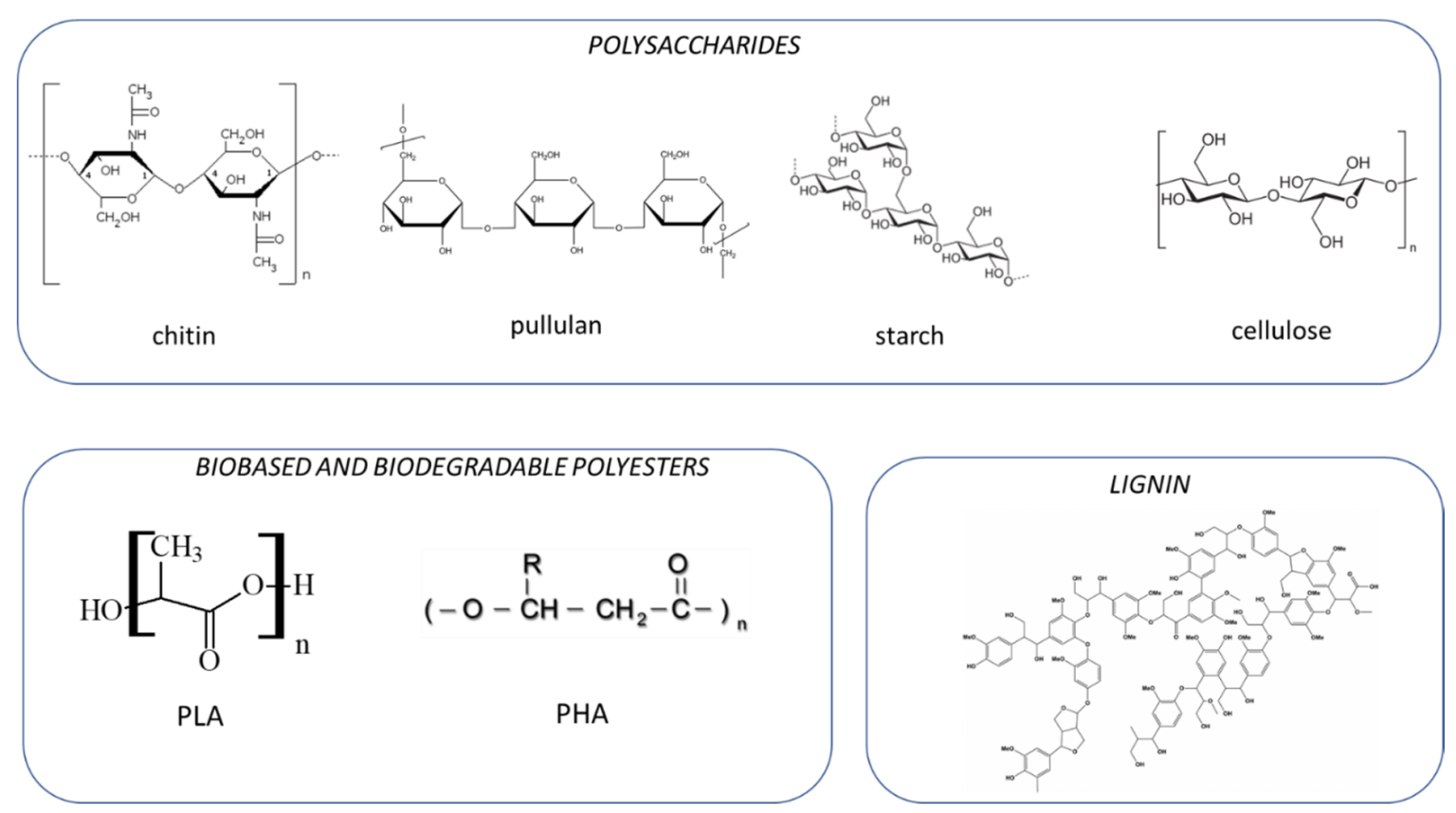

Figure 6. Biopolymers considered for producing a surgical face mask (SFM) and a beauty face mask (BFM).

Lignin, obtained from forestry and agro-food waste, can be considered another useful material in SFM and BFM for its intrinsic antioxidant properties also. Moreover, being an electronegative hydrosoluble polymer, forms in water complexes with chitin nanofibrils. These complexes have been studied as potential carriers of active biomolecules for cosmetic and biomedical applications [47].

All these biobased materials can be considered for producing SFMs or BFMs so that their applications, advantages and disadvantages are reported in Table 1, where chitin nanofibrils-lignin complexes (CN-LG), PLA, PHA, pullulan or starch and cellulose were compared, considering their processing properties and end-life, when used as the main materials for this use.

Among the many polysaccharides and natural polymers, chitin and lignin, seem to represent a good alternative, being obtainable in great quantity from food waste and agro-forestry biomass respectively $[46,47]$. These polymers are the most abundant natural polymers considered as prospective raw materials suitable to produce green surgical and beauty masks according to our previous research activities [48-50]. Moreover both the polymers have shown to have antibacterial, antioxidant and skin regenerative activity, suitable to realize innovative and biodegradable tissues [51-53]. Chitin and lignin, being nontoxic compounds that are easily biodegradable, have been used in their nanosizes (i.e., chitin nanofibrils (CN) and nanolignin (LG)) to increase their effectiveness in realizing non-woven tissues [54] and films $[55,56]$, because of the higher surface-to-volume ratio in respect to their normal dimensions. Their application seems to be more suitable to produce directly BFMs by the use of electrospun tissues, characterized for their antioxidant, antimicrobial and cell's regenerative effectiveness. In the case of SFMs, the CN-LG complexes can be used to modify polymeric substrates, through methodologies such as powder impregnation and water based coatings [47]. Interestingly CN-LG complexes can act as carrier of various functional molecules and this possibility was successfully evidenced incorporating into the CN-LG glycyrrhetic acid, extracted from the liquorice plant [57]. This acid, in fact, possesses evident antimicrobial and anti-inflammatory properties useful for the surgical masks.

However, it is important to remember that many other common biodegradable polymers used in skin tissue regeneration are either natural or man-made, such as starch, cellulose, gelatin, pullulan or polylactic acid (PLA), polyglycolic acid (PGA), PGA-PLA copolymers and polyhydroxyalkanoates (PHA). All these polymers, as previously reported, have shown various advantages or disadvantages when used for tissue production but can be adopted in dependence of 
the desired final properties. PLA, for example, has a high modulus of elasticity and tensile strength but shows also inherent brittleness and low toughness [58]. However, it can be a very good candidate to produce conventional non-woven tissues with a cost similar to the current PP based version. Moreover, the recycling of the masks can be possible as well as its composting in industrial plants [59]. Thus, technologies to modulate PLA based blend properties [60-64] as well as the incorporation of chitin nanofibrils or other nanostructured fillers [65-67] have yet to be deeply investigated. It has been shown that these fillers potentiate specific properties of PLA based materials, just as for instance, the incorporation of chitin nanofibrils [68]. Thus, pure PLA or its blends with other biodegradable biopolyesters can be easily processed by traditional non-woven techniques to make SFMs.

Table 1. Fully renewable and biodegradable polymers highly compatible with skin that can be used in surgery face masks (SFM) or beauty face masks (BFM).

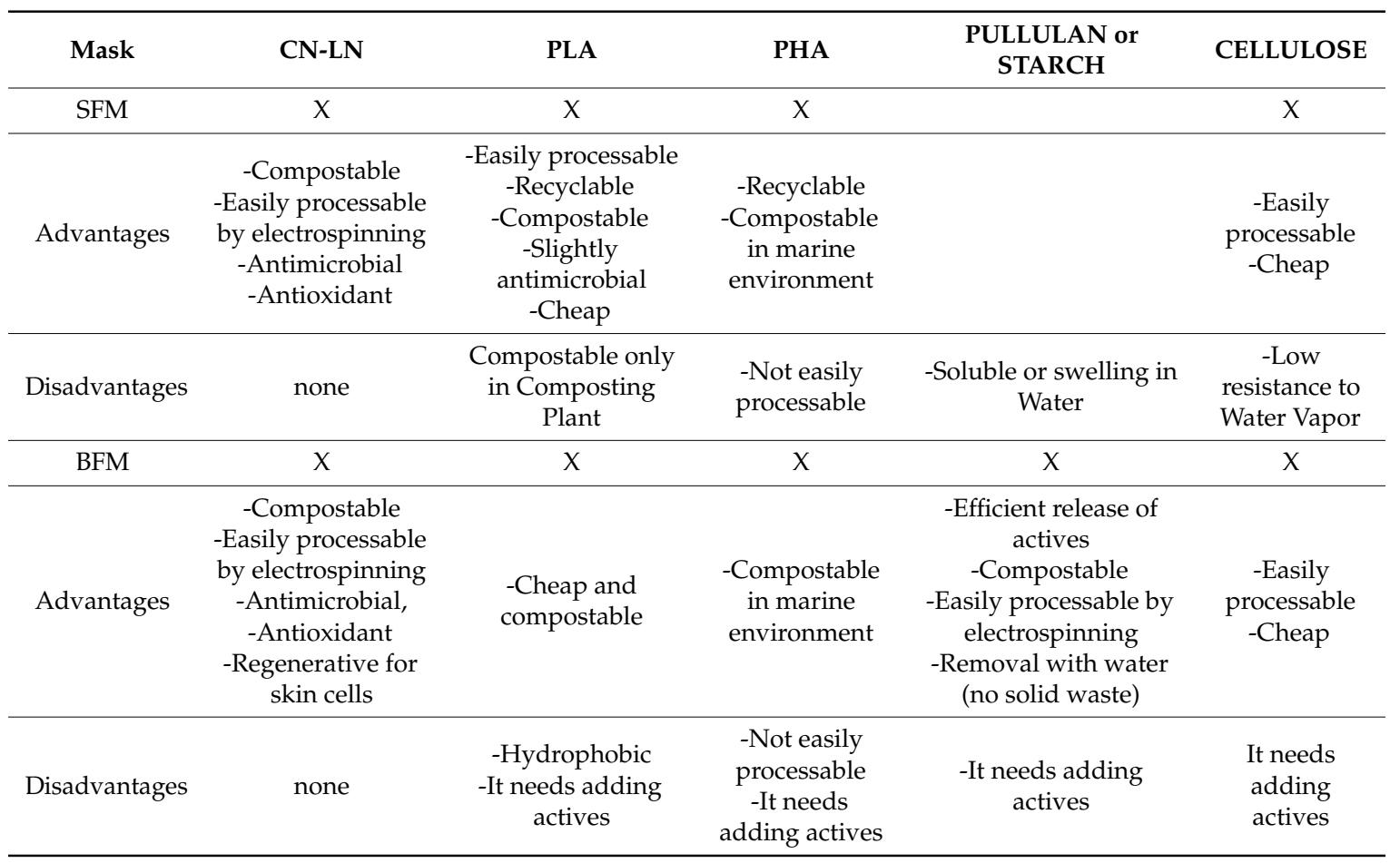

CN-LG = chitin nanofibrils-lignin complexes; PLA = poly(lactic acid); PHA = poly(hydroxyalcanoate); SFM = Surgical Face Masks (SFM); BFM = Beauty Face Masks (BFM).

On the one hand, hydrophobicity of PLA makes it suitable as a protective external film/tissue to be used as support for the BFMs fabrication. On the other hand PLA based composites with natural fibers [69-71] or nanocomposites with a higher hydrophilicity can be of utility for producing other suitable layers of non-woven tissues. The advantage of collecting the post-consumer BFM in the organic fraction of waste can improve the end of life of these products with respect to current versions where mixtures of natural and fossil fibers are used and mainly disposed by landfill.

PLA does not have intrinsic functional properties, although a slight antimicrobial behavior was evidenced $[63,67]$ and attributed to the presence on its surface of a low concentration of lactic acid, known as a biocide. Hence the coating of PLA non-woven and their substrates with functional compounds incorporating antioxidant, anti-inflammatory and skin regenerative properties, seems to be a relevant process, yet studied by several authors. Miletić et al. [72] developed active coatings with modified and unmodified chitin-lignin nanoparticle complexes to apply them on extruded PLA-based sheets.

On the other hand, the use of PHA can result in the advantage of a tissue or film that should have a very high compatibility with skin, as demonstrated in research studies where compression molded or extruded PHA/starch BFMs based elastic films were produced, with starch acting as a carrier to 
be applied on the skin [71,73]. The PHA provides the possibility to degrade the mask also in the marine environment [73]. So, in the case that the mask is accidentally lost in the environment, this can be an advantage against littering and marine pollution. Unfortunately, its very narrow processing temperature range may limit its application in several fields.

The use of pullulan [74] or starch results in not being suitable for the SFMs, because these biopolymers are soluble or easily swell out in water. Hence the water vapor of human breathing can induce the partial dissolution of the mask. On the other hand, these polymers are much more interesting for the use in BFMs, as they can produce tissues that dissolve on the wet skin, rapidly releasing the biodegradable cosmetic active ingredients. Moreover, they do not induce the production of solid waste, as they can be removed by washing the skin.

Cellulose may be another cheap alternative to process both SFMs and BFMs by consolidated technologies. However, its hygroscopicity can induce some instability due to the water vapor of breathing and the cellulose fibers, which tend to be pulped by water. Anyway, for a beauty mask pure cellulose seems to be a valid and good support.

Among the biobased, biodegradable and coating materials, chitin nanofibrils can be used as a functional additive for tissues, such as for example PLA films [75] or cellulosic substrates [76]. It is also interesting to underline that chitin nanofibrils have been shown to increase not only the tensile strength and Young modulus of various composites made, for example by chitosan $[56,76]$ or polylactic acid (PLA) [75,77], but also to stimulate the skin differentiation and maturation of CD34-posive cells of rats with the characteristics of stem cells, for example, at the level of the hair bulb (Figure 7) [78]. As it appears from the reported immuno-histochemical study, the CD34-positive cells appear to be more expressed in skin treated by $\mathrm{CN}$ and $\mathrm{CN}$-Lutein compared with the non-treated control (Figure 7).

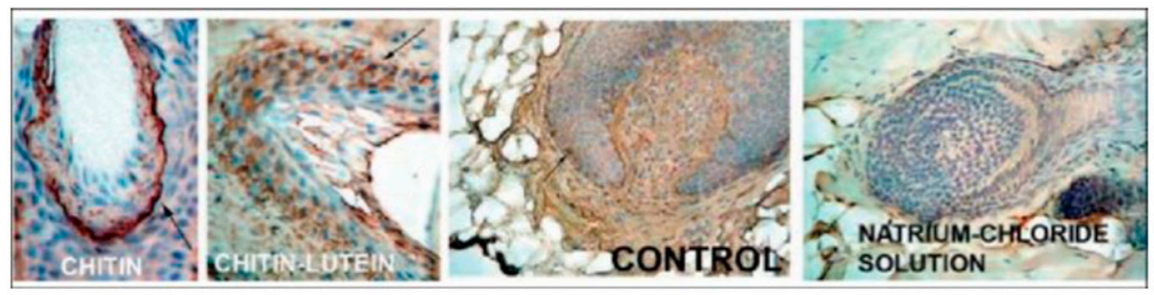

Figure 7. Faster stem cells reproduction onto hair treated by chitin nanofibrils binding lutein [78].

On the other hand, the interesting stimulus activity on CD-34-positive radicular-follicular (i.e., stem) cells reported from our group some years ago [78] has been confirmed recently from other research groups [79-82]. Thus, it has shown an increasing activity of anagen hair follicles of mice treated topically by chitosan and $\mathrm{CN}$ with a contemporary decrease in the number of catagen follicles, compared with the control group [82]. Additionally, it has shown a faster repairing activity on wounded and burned skin of mice and humans skin treated by CN tissue [83-91]. The activity on the stem cell could be one of the probable reasons of the skin repairing activity shown from $\mathrm{CN}$ tissues, used in vivo by surgical medications to repair the skin affected by burns of the first and second degree $[83,86]$. It has been shown, in fact, a faster repairing activity of the burned skin treated by $\mathrm{CN}$ tissues in comparison with the normal medication in use into the plastic surgery hospital department [86].

What is the reason of the reinforcing activity of chitin nanofibrils when used as a filler to realize nanocomposites with chitosan [76] or polylactic acid [56,71,73]. According to the Yudin group research studies [76], it has been supposed that $\mathrm{CN}$ "contributes to the orientation of the chitosan macromolecule that leads to an increased strength and elastic Young module of the composite fibers" as reported on Figure 8, contributing also to the degradability and sustainability of the nanocomposite processing $[67,68,76,77]$. The introduction of $\mathrm{CN}$ into the chitosan matrix could contribute to form a more bioresorbable composite, increasing its biocompatibility, bioactivity, hemocompatibility and effectiveness at the skin level [76,79-81]. 


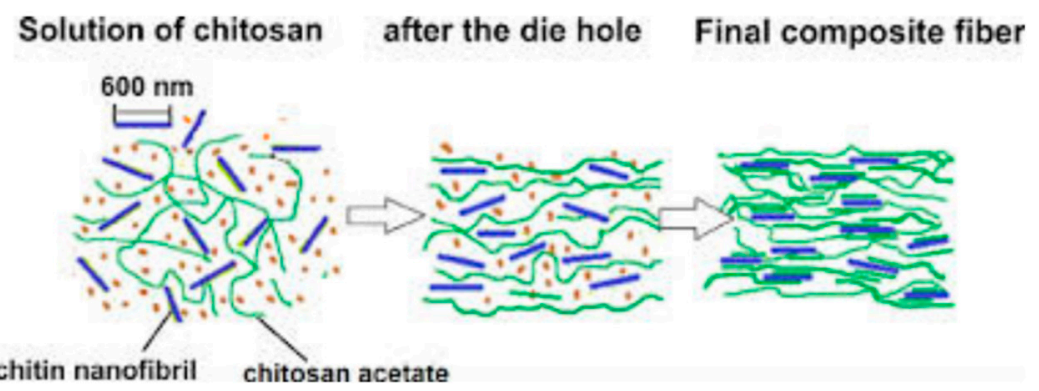

Figure 8. Nanocomposite structure organization made by chitosan fibers (green) and chitin nanofibrils (blue) [76].

All the data shown by the reported research studies both in vitro and in vivo [52,53,83-85] could explain, therefore, part of the mechanism of the action CN and CN-LG may have on skin, when linked to the fibers' tissue, made by biopolysaccharide polymers. According to the active ingredients linked to $\mathrm{CN}$ and the relative obtained complexes, the tissue may have high regenerative effectiveness on aged skin $[40,57,87-89]$ or a faster repairing activity on wounded or burned skin $[40,51,52,83-86]$. Additionally as previously reported, we underline the possibility to realize $\mathrm{CN}$ films made by short fibers, which, being strictly compressed each to others, are able to filter and stop the entry of microorganisms. On the other hand, the $\mathrm{CN}$-non-woven tissues, made by longer fibers connected to each other with a morphology characterized by many holes, may facilitate the interchanging of oxygen and carbon dioxide with the cells.

\section{Conclusions}

In conclusion, it is possible to design innovative multilayered surgical face masks made from biodegradable films and non-woven tissue. Thus on the one hand they may reduce the likelihood of being infected with viruses and a microbiome, such as COVID-19, while on the other hand they may favor mouth and nose perspiration. Moreover, both films and non-woven tissues [89-91] can be modified by incorporation, impregnation, coatings or grafting techniques with specific ingredients, possessing specific properties, such as bactericidal, anti-inflammatory, skin repairing and being easily degraded or recycled. On the other hand, the current commercial surgical masks, being made of different polymeric materials, are not recycled. This is the reason why many research groups are trying to develop mono-material products to be traced, selectively collected and recycled.

Additionally, it is also possible to make beauty masks, realized by non-woven tissues made by natural fibers and activated by ingredients for hydrating, antiaging, whitening and other cosmetic activities.

These new and smart beauty masks, processed and distributed in the dry state, and activated by water, only when used, may be considered innovative and safe because they are free of preservatives, emulsifiers, colors, fragrances and other chemicals [22,49,50,71-73,86]. The active ingredients, in fact, are directly linked to the tissue's fibers, during the producing process $[49,50,57,87-89,91]$. It is also important to underline that all the carriers (tissues and films) and the ingredients proposed are of a natural origin, totally biodegradable, skin and environment friendly. Moreover, according to the last consumers' requests and the normal cosmetic principles, these sustainable, genderless and smart beauty masks, focused on natural-derived ingredients and innovative technologies, could be characterized to have more effectiveness against pollution, blue-light and skin aging.

In conclusion, according to the circular-green economy principles and in line with current scientific knowledge, both the surgical and beauty face masks could be made by ingredients obtained from renewable and biodegradable materials, thus contributing to reducing the pollutive worldwide waste and maintaining natural raw materials and the planet' biodiversity for future generations. 
Author Contributions: Conceptualization, P.M. and M.-B.C.; investigation and data curation, G.M., V.E.Y. and P.M.; writing—original draft preparation, P.M.; writing—review and editing, M.-B.C.; supervision, V.E.Y. All authors have read and agreed to the published version of the manuscript.

Funding: This research received no external funding.

Conflicts of Interest: The authors declare no conflict of interest.

\section{References}

1. Baka, A.; Cenciarelli, O.; Duffell, E.; Melidou, A.; Pettinen, P.; Plachous, D. Using Face Masks in the Community. European Centre od Disease Prevention and Control. European Centre for Disease Prevention and Control (ECDC) Technical report. 8 April 2020. Available online: https://www.ecdc.europa.eu/en/publications-data/ using-face-masks-community-reducing-covid-19-transmission (accessed on 22 August 2020).

2. Nilforoushzadeh, M.A.; Amirkhani, M.A.; Zarrintaj, P.; Moghaddam, A.S.; Mehrabi, T.; Alavi, S. Skin Care and Rejuvenation by Cosmeceutical Facial Mask. J. Cosmet. Derm. 2018, 17, 693-702. [CrossRef]

3. Chellamani, K.P.; Veerasubramanian, D.; Vignesh Balaji, R.S. Surgical Face Masks: Manufacturing Methods and Classification. J. Acad. Ind. Res. (JAIR) 2013, 2, 320-324.

4. European Commission. Horizon 2020, Work Programme 2018-2020, Nanotechnology, Advanced Materials, Biotechnology and Advanced manufacturing and Processing. European Commission Decision No1862. 25 March 2020. Available online: https://ec.europa.eu/research/participants/data/ref/h2020/wp/2018-2020/ main/h2020-wp1820-leit-nmp_en.pdf (accessed on 15 July 2020).

5. Song, R.; Murphy, M.; Li, C.; Soo, C.; Zheng, Z. Current Development of Biodegradable Polymeric Materials for Biomedical Applications. Drug Design Develop. Ther. 2018, 12, 3117-3145. [CrossRef]

6. Sell, S.A.; Wolfe, P.S.; Garg, K.; McCool, J.M.; Rodriguez, I.A.; Bowling, G.L. The use of Natural Polymes in Tissue Engineering: A Focus on Electrospun Extracellular Matrix Analogues. Polymers 2020, $2,522$. [CrossRef]

7. Lackner, M. Chapter Bioplastics. Biobased Plastics as Renowable and/or Biodegradable Alternative to Petroplastics. In Encyclopedia of Chemical Technology, 6th ed.; Othmer, K., Ed.; Jhon Wiley \& Sons: Hoboken, NJ, USA, 2015.

8. Worldometer-Real Time World Statistics. Available online: https://www.worldometers.info (accessed on 15 July 2020).

9. Wong, A.; Wilkinson, A. Surgical Face Masks-Filtering Counterfeit Copies Bird \& Bird. 2020. Available online: https://www.twobirds.com/EU/news/articles (accessed on 1 May 2020).

10. Merchant Research \& Consulting Ltd. (2020) Polypropylene (PP): 2020 World Market Outlook and forecast up to 2029. Available online: https://mcgroup.co.uk/researches/polypropylene-pp (accessed on 15 July 2020).

11. WHO. Advice on the Use of Masks in the Contest of COVID-19; World Health Organization: Geneva, Switzerland, 2020.

12. McKornick. COVID-19 Airway Protection on PPE Overview; Report McKornick \& Company: New York, NY, USA, 2020.

13. Sivri, C. Improvement of protective and comfort properties of face masks using superabsorbent polymer containing nanofibers. Int. J. Chot. Sci. Technol. 2018, 30, 668-686. [CrossRef]

14. European Union. Manual on Borderline and Classification in the Community Regulatory Framework for Medical Device, version 1.22 (May 2019); European Union: Bruxelles, Belgium, 2019.

15. WHO. Medical Devices: Managing the Mismatch-An Outcome of the Priority Medical Devices Project; World Health Organization: Geneve, Switzerland, 2010; ISBN 9789241564045.

16. Globe Newswire. Face Market to Surpass USD Billion by 2026; Market Study Report: Selbyville, DE, USA, 2020. Available online: https://www.globenewawire.com (accessed on 5 May 2020).

17. Market Watch. Industry Analysis, Growth, Trends, Key Players and Forecast 2020-2026. Available online: https://www.marketwatch.com (accessed on 5 May 2020).

18. Gran View Research. Disposable Face Mask Market Size, Share \& Trends Analysis Report by Product, by Application and Segment Forecasts, 2020-2027. 2020. Available online: https://www.grandreviewresearch. com (accessed on 6 May 2020).

19. Moelling, K.; Broecker, F. Air Microbiome and Pollution:Composition and Potential Effects of Human Health, Including SARS Coronavirus Infection. J. Environ. Pub. Health 2020, ID1646943, 14P. [CrossRef] 
20. Technavio Web-Site. Available online: https://www.technavio.com (accessed on 15 July 2020).

21. Spiritelli, C. Cosmetic Industry: An Analysis of Marketing and Mass Communication Strategies. Master's Thesis, Lecterature Depart, Padoa University, Padoa, Italy, 2019.

22. Morganti, P.; Morganti, G.; Chen, H.-D.; Gagliardini, A. Beauty Mask: Market and Environment. J. Clin. Cosmet. Dermatol. 2019, 3,1-10. [CrossRef]

23. Statista. Beauty E Personal Care Report 2019. Statista Consumer Market Outlook, Market Report. May 2019. Available online: https://www.statista.com (accessed on 6 May 2020).

24. Bhadallar, S. Sheet Face Masks Market by Product Type, Price Point and Distribution Channel: Global Opportunity Analysis and Industry Forecast, 2018-2026, Allied Market Research. 2019. Available online: https://www.alliedmarketresearch.com (accessed on 6 May 2020).

25. Zhang, L.; Adique, A.; Sarkar, P.; Shenai, V.; Sampath, M.; Lai, R. The Impact of Routine SkinCare on The Quality of Life. Cosmetics 2020, 7, 59. [CrossRef]

26. Gran View Research. Sheet Face Mask Market Size, Share \& Trends Analysis Report by Product Type (Cotton, non-woven, hydro gel, biocellulose) by Region and Segment Forecast 2019-2025. 2020. Available online: https://www.granviewresearch.com/industry-analysis/sheet-face-maskmarket (accessed on 6 May 2020).

27. Kwek, S.; Mintel, G.N.P.D. Global New Products Database: Tracked, Analyzed, Explained. Mintel Group Ltd.. Available online: https://www.mintel.com/global-new-products-database (accessed on 7 May 2020).

28. Ritchie, H.; Roser, M. Plastic Pollution. Available online: https://www.ourworldindafa.org/plasticpollution (accessed on 7 May 2020).

29. Ritchie, H. The Carbon Footprint of Foods: Are Differences Explained by the Impacts of Methane? Available online: https://www.ourworldindata.org/carbonfootprint-food-methane (accessed on 7 May 2020).

30. Jambeck, J.R.; Geyer, R.; Wilcox, C.; Perryman, M.; Andrady, A. Plastic Waste Inputs from Land into the Ocean. Science 2015, 347, 768-771. [CrossRef]

31. Statista. Plastic Waste Worldwide-Statistics \& Facts. Available online: https://www.statista.com (accessed on 13 May 2020).

32. Sensoneo. Global Waste Index 2019. Available online: https://www.sensoneo.com/references/ (accessed on 7 May 2020).

33. IMF. Global Wellnes Economy Monitor, Global Economy Outlook Data Base, Global Wellness Institute. April 2018. Available online: https://www.imf.org/external/pubs/ft/Wei/2018/01/welfare/index.aspx (accessed on 15 July 2020).

34. Ellen Mac Arthur Foundation. From Linear to Circular Economy. A global learning Programme. Ellen Mac Arthur Foundation. 15 April 2020. Available online: https://www.ellenmacarthurfoundation.org (accessed on 15 July 2020).

35. Ocean Crusaders. Plastic Statistics. Plastic Ain't so Fantastic, Ocean Crusaders Foundation Ltd. Available online: https://www.oceancrusaders.org (accessed on 13 May 2020).

36. Kwek, S. Face Masks Fuel Post-Covid-19 Beauty Opportunie. Mintel UK. 2020. Available online: https: //www.mintel.com/blog/beauty-market-news/face-masks-fuelpost-covid-19-beauty-opportunities (accessed on 7 May 2020).

37. Angus, A. How is COVID-19 affecting the Top 10 Global Consumer Trends 2020? Euromonitor International. 2020. Available online: https://go.euromonitor.com/webinar-ec-2020-covid-19-impact-on-gct.html (accessed on 15 July 2020).

38. Angus, A.; Westbrook, G. Top 10 Global Consumer Trends; Euromonitor International: London, UK, 2019. Available online: https://go.euromonitor.com/white-paper-EC-2019-Top-10-Global-Consumer-Trends.html (accessed on 15 July 2020).

39. Jindal, S.; Kwek, S.; McDougall, A. Global Beauty and Personal Care Trends 2030; Mintel: London, UK, 2020. Available online: https://www.mintel.com/beauty-trends (accessed on 15 July 2020).

40. Morganti, P.; Morganti, G.; Coltelli, M.B. Chitin Nanomaterials and Nanocosmetics for Tissue Repair. In Marine-Derived Biomaterials for Tissue Engineering; Choi, A.H., Ben-Nissan, B., Eds.; Spring: Singapore, 2019; pp. 523-544.

41. Tuin, A.; Pourdeyhimi, B.; Loboa, E.G. Creating Tissues from Textiles: Scalable Nonwoven Manufacturing Techniques for Fabrication of Tissue Engineering Scaffolds. Biomed. Mater. 2016, 11, 015017. [CrossRef] 
42. Aires, C.E.; Sheehan Jha, B.; Sell, S.A.; Bowin, G.L.; Simpson, D.G. Nanotechnology in the design of Self Tissue scaffolds: Innovation in structure and function. WIREs Nanomed. Nanobiotechnol. 2010, 2, $20-34$. [CrossRef] [PubMed]

43. Agarwal, S.; Wendorff, J.H.; Greiner, A. Use of electrospinning technique for biomedical applications. Polymer 2008, 49, 5603-5621. [CrossRef]

44. Fuller, K.; Pandit, A.; Zeugolis, D.I. The multifaceted Potential of Electrospinnig in Regenerative Medicine. Pharm. Nanotechnol. 2014, 2, 23-34. [CrossRef]

45. Parham, S.; Kharazi, A.Z.; Bakhsheshi-Rad, H.R.; Ghayour, H.; Ismail, A.F.; Nur, H.; Berto, F. Electrospun Nano-Fibers for Biomedical and Tissue Engineering Applications: A Comprehensive Review. Materials 2020, 13, 2153. [CrossRef]

46. Morganti, P. Chitin Nanofibrils: Tuning Fishery's Waste into Goods. J. Clin. Rev. Case Rep. 2018, 3, 1-3.

47. Morganti, P.; Chen, H.D.; Gao, X.; Morganti, G.; Febo, D. Chitin \& Lignin:Tuning Food Waste into Cosmeceuticals. J. Clin. Cosmet. Dermatol. 2018, 3, 1-10. [CrossRef]

48. Morganti, P.; Febo, P. Innovative tissue engineering for an enlarged Market. J. Clin. Cosmet. Derm. 2017, 2, 119. [CrossRef]

49. Morganti, P.; Coltelli, M.B.; Danti, S. Biobased tissues for Innovative Cosmetic products: PolyBioSkin as an EU Resarch Project. Glob. J. Nano Case Rep. 2018, 3, 555620. [CrossRef]

50. Morganti, P.; Coltelli, M.B. A New Carrier for Advanced Cosmeceuticals. Cosmetics 2019, 6, 10. [CrossRef]

51. Morganti, P.; Del Ciotto, P.; Stoller, M.; Chianese, A. Antibacterial and Antiinflammatory Green Nanocomposites. Chem. Eng. Trans. 2016, 47, 6-66. [CrossRef]

52. Morganti, P.; Fusco, A.; Paoletti, I.; Perfetto, B.; Del Ciotto, P.; Palombo, M.; Chianese, A.; Baroni, A.; Donnarumma, G. Anti-Inflammatory, Immunomodulatory, and Tissue Repair Activity on Human Keratinocytes by Green Innovative Nanocomposites. Materials 2017, 10, 843. [CrossRef] [PubMed]

53. Morganti, P.; Stoller, M. Chitin Natural Ingredients from Waste Materials to Make Innovative and Heakthy Products for Humans and plant. Chem. Eng. Trans. 2017, 48, 319-324. [CrossRef]

54. Xu, X.G.; Gao, X.H.; Chen, H.D.; Morganti, P. Chitin Nanocomposite Scaffolds for Advanced Medications. In Bionanotechnolgy to Save the Environment. Plant and Fishery's Biomass as Alternative to Petrol; Morganti, P., Ed.; MDPI: Basel, Switzerland, 2019; pp. 260-271.

55. Morganti, P.; Tishchenko, G.; Palombo, M.; Kelnar, I.; Brozova, L.; Spirkova, M. Chitin Nanofibrils for Biomimetic Products: Nanoparticles and Nanocomposites Chitosan Films in Health Care. In Marine Biomaterials. characterization Isolation and Applications; Kim, S.K., Ed.; CRC Press: Boca Raton, FL, USA, 2013; pp. 681-716.

56. Tishchenko, G.; Morganti, P.; Stoller, M.; Kelnar, I.; Mikesova, J.; Kovarova, J. Chitin Nanofibrils-Chitosan Composite Films: Characterization and Properties. In Bionanotechnolgy to Save The Environment. Plant and Fishery's Biomass as Alternative to Petrol; Morganti, P., Ed.; MDPI: Basel, Switzerland, 2019; pp. 191-226.

57. Danti, S.; Trombi, L.; Fusco, A.; Azimi, B.; Lazzeri, A.; Morganti, P.; Coltelli, M.B.; Donnarumma, G. Chitin Nanofibrils and Nanolignin as Functional Agents in Skin Regeneration. Int. J. Mol. Sci. 2019, $20,2669$. [CrossRef] [PubMed]

58. Hamad, K.; Kanseem, M.; Yang, H.W.; Deri, F.; Ko, Y.G. Properties and medical Applications of polylactic acid: A review. Express Polym. Lett. 2015, 9, 435-455. [CrossRef]

59. de Andrade, M.F.C.; Souza, P.M.S.; Cavalett, O. Life Cycle Assessment of Poly (Lactic Acid) (PLA): Comparison Between Chemical Recycling, Mechanical Recycling and Composting. J. Polym. Environ. 2016, 24, 372-384. [CrossRef]

60. Coltelli, M.B.; Della Maggiore, I.; Bertoldo, M.; Bronco, S.; Signori, F.; Ciardelli, F. Poly (lactic acid) (PLA) properties as a consequence of poly (butylene adipate-co-terephtahlate) (PBAT) blending and acetyl tributyl citrate (ATBC) plasticization. J. Appl. Polym. Sci. 2008, 110, 1250-1262. [CrossRef]

61. Coltelli, M.B.; Bronco, S.; Chinea, C. Effect of free radical reactions onto Structure and properties of poly (lactic acid) (PLA) based blends. Polym. Degr. Stab. 2010, 95, 332-341. [CrossRef]

62. Coltelli, M.-B.; Toncelli, C.; Ciardelli, F.; Bronco, S. Compatible blends of biorelated polyesters through catalytic transesterification in the melt. Polym. Degr. Stab. 2011, 96, 982-990. [CrossRef]

63. Gigante, V.; Coltelli, M.B.; Vannozzi, A.; Panariello, L.; Fusco, A.; Trombi, L.; Donnarumma, G.; Danti, S.; Lazzeri, A. Flat Die Extruded Biocompatible Poly (Lactic Acid) (PLA)/Poly (Butylene Succinate) (PBS) Based Films. Polymers 2019, 11, 1857. [CrossRef] 
64. Coltelli, M.-B.; Cinelli, P.; Gigante, V.; Aliotta, L.; Morganti, P.; Panariello, L.; Lazzeri, A. Chitin Nanofibrils in Poly (Lactic Acid) (PLA) Nanocomposites: Dispersion and Thermo-Mechanical Properties. Int. J. Mol. Sci. 2019, 20, 504. [CrossRef]

65. Castiello, S.; Coltelli, M.-B.; Conzatti, L.; Bronco, S. Comparative study about preparation of poly (lactide) (PLA)/organophilic montmorillonites nanocomposites through melt blending or ring opening polymerization methods. J. Appl. Polym. Sci. 2012, 125, 413-428. [CrossRef]

66. Scatto, M.; Salmini, E.; Castiello, S.; Coltelli, M.B.; Conzatti, L.; Stagnaro, P.; Andreotti, L.; Bronco, S. Plasticized and nanofilled Poly (Lactic Acid)-based cast films: Effect of plasticizer and organoclay on processability and final properties. J. Appl. Polym. Sci. 2013, 127, 4947-4956. [CrossRef]

67. Coltelli, M.-B.; Aliotta, L.; Vannozzi, A.; Morganti, P.; Panariello, L.; Danti, S.; Neri, S.; Fernandez-Avila, C.; Fusco, A.; Donnarumma, G.; et al. Properties and Skin Compatibility of Films Based on Poly (Lactic Acid) (PLA) Bionanocomposites Incorporating Chitin Nanofibrils (CN). J. Funct. Biomater. 2020, 11, 21. [CrossRef] [PubMed]

68. Gigante, V.; Aliotta, L.; Phuong, T.V.; Coltelli, M.B.; Cinelli, P.; Lazzeri, A. Effects of waviness on fiber-length distribution and interfacial shear strength of natural fibers reinforced composites. Compos. Sci. Technol. 2017, 152, 129-138. [CrossRef]

69. Aliotta, L.; Gigante, V.; Coltelli, M.B.; Cinelli, P.; Lazzeri, A. Evaluation of Mechanical and Interfacial Properties of Bio-Composites Based on Poly (Lactic Acid) with Natural Cellulose Fibers. Int. J. Mol. Sci. 2019, 20, 960. [CrossRef]

70. Coltelli, M.-B.; Danti, S.; Trombi, L.; Morganti, P.; Donnarumma, G.; Baroni, A.; Fusco, A.; Lazzeri, A. Preparation of Innovative Skin Compatible Films to Release Polysaccharides for Biobased Beauty Masks. Cosmetics 2018, 5, 70. [CrossRef]

71. Coltelli, M.-B.; Panariello, L.; Morganti, P.; Danti, S.; Baroni, A.; Lazzeri, A.; Fusco, A.; Donnarumma, G. Skin-Compatible Biobased Beauty Masks Prepared by Extrusion. J. Funct. Biomater. 2020, 11, 23. [CrossRef]

72. Miletić, A.; Ristić, I.; Coltelli, M.-B.; Pilić, B. Modification of PLA-Based Films by Grafting or Coating. J. Funct. Biomater. 2020, 11, 30. [CrossRef]

73. Sashiwa, H.; Fukuda, R.; Okura, T.; Sato, S.; Nakayama, A. Microbial Degradation Behavior in Seawater of Polyester Blends Containing Poly(3-hydroxybutyrateco-3-hydroxyhexanoate) (PHBHHx). Mar. Drugs 2018, 16, 34. [CrossRef]

74. Coltelli, M.B.; Danti, S.; De Clerck, K.; Lazzeri, A.; Morganti, P. Pullulan for Advanced Sustainable Body and Skin-Contact Applications. J. Funct. Biomater. 2020, 11, 20. [CrossRef]

75. Panariello, L.; Coltelli, M.B.; Buchignani, M.; Lazzeri, A. Chitosan and nano-structured chitin for biobased anti-microbial treatments onto cellulose based materials. Eur. Polym. J. 2019, 113, 328-339. [CrossRef]

76. Yudin, V.E.; Dobrovolskaya, I.P.; Neelov, I.M.; Dresvianina, E.N.; Popryadukhin, P.V.; Ivankova, E.M.; Elokhovskii, V.Y.; Kasatkin, I.A.; Okrugin, B.M.; Morganti, P. Wet spinning of fibers made of chitosan and chitin nanofibrils. Carbohydaste Polym. 2014, 108, 176-182. [CrossRef] [PubMed]

77. Cinelli, P.; Coltelli, M.B.; Mallegni, N.; Morganti, P.; Lazzeri, A. Degradability and Sustainability of Nanocomposites Based on Polylactic acid and Chitin Nanofibrils. Chem. Eng. Trans. 2017, 48, 115-120. [CrossRef]

78. Biagini, G.; Zizzi, F.; Giantomassi, F.; Orlando, F.; Lucarini, G.; Mattioli-Belmonte, M.; Tucci, M.G.; Morganti, P. Cutaneous Absorption of Nanostructured Chitin Associated with Natural Synergistic molecules (Lutein). J. Appl. Cosmetol. 2008, 26, 69-80.

79. Shabunin, A.S.; Yudin, V.E.; Dobrovolskaya, I.P.; Zinovyev, E.V.; Zubov, V.; Ivankova, E.; Morganti, P. Composite wound dressing based on Chitin/Chitosan nanofibrils: Processing and biomedical applications. Cosmetics 2019, 6, 16. [CrossRef]

80. Smirnova, N.V.; Kolbe, K.A.; Dresvyanina, E.N.; Grebennikov, S.F.; Dobrovolskaya, I.P.; Luxbacher, T.; Morganti, P. Effect of Chitin Nanofibril on Biocompatibility and Biodiversity of the Chitosan-based Composite Film Matrix Intended for Tissue Engineering. Materials 2019, 12, 1874. [CrossRef]

81. Maevskaia, E.N.; Kirichuk, O.P.; Kuznetzov, S.I.; Dresvyanina, E.N.; Yudin, V.V.; Morganti, P. Hemocompatible Chitin-Chitosan Composite Fibers. Cosmetics 2020, 7, 28. [CrossRef]

82. Azuma, K.; Koizumi, R.; Izawa, H.; Morimoto, M.; Osaka, T.; Saimoto, H.; Ito, N.; Yamashita, M.; Tsuka, T.; Imagawa, T.; et al. Hair Growth-Promoting Activities of Chitosan and Surface-deacetylated Chitin Nanofibrils: Processing and Biomedical Applications. Int. J. Biol. Macromol. 2018, 126, 11-17. [CrossRef] 
83. Jui, Y.Y.; Chin, T.L.; Ing, T.S.; Cardillo, M.; Morganti, P. Cross-Sectional Study Design and Data Analysis of the Effect of Chitin Nanofibriks-Lignin Micro/Nano Particles on Nakaysua's Subject with Disorders. J. Clin. Cosmet. Derm. 2019, 3, 1-6. [CrossRef]

84. Morganti, P.; Anniboletti, T.; Pollastrini, C.; Morganti, G. Natural Polymers for Body Care to Save the Environment. Biomed. J. Sci. Tech. Res. 2019, 17, 12570-12574. [CrossRef]

85. Donnarumma, G.; Fusco, A.; Morganti, P.; Palombo, M.; Anniboletti, T.; Del Ciotto, P.; Baroni, A.; Chianese, A. Advances Medications made by Green Nanocomposites. Int. J. Res. Nano Sci. 2018, 5, 261-270.

86. Anniboletti, T.; Palombo, M.; Maroni, S.; Bruno, A.; Palombo, P.; Morganti, P. Clinical Activity of Innovative Polymeric Nanoparticles and Non-woven Tissues. In Bionanotechnology to Save the Environment. Plant and Fishery's Bioamass as Alternative to Petrol; Morganti, P., Ed.; MDPI: Basel, Switzerland, 2019; pp. 340-360.

87. Morganti, P.; Palombo, M.; Tishchenko, G.; Yudin, V.E.; Guarneri, F.; Cardillo, M.; Del Ciotto, P.; Carezzi, F.; Morganti, G.; Fabrizi, G. Chitin-Hyaluronan Nanoparticles: A Multifunctional Carrier to Deliver Anti-Aging Active Ingredients through the Skin. Cosmetics 2014, 1, 149-158. [CrossRef]

88. Morganti, P.; Morganti, G.; Coltelli, M.B. Skin and Pollution: The Smart Nano-Based Cosmeceutical-Tissue to Save the Planet Ecosystem. In Nanocosmetics: Fundamentals, Applications and Toxicity; Nanda, A., Nanda, S., Nguyen, T.A., Rajendran, S., Slimani, Y., Eds.; Elsevier: Amsterdam, The Netherland, 2020; pp. 287-304.

89. Morganti, P.; Chen, H.D.; Morganti, P. Nanocosmetics: Future Perspective. In Nanocosmetics: Fundamentals, Applications and Toxicity; Nanda, A., Nanda, S., Nguyen, T.A., Rajendran, S., Slimani, Y., Eds.; Elsevier: Amsterdam, The Netherland, 2020; pp. 455-481.

90. Sakamoto, K.; Lochhead, R.Y.; Maybach, H.I.; Yamashita, Y. Cosmetic Science and Technology Principles and Applications; Elsevier: Amsterdam, The Netherlands, 2017.

91. Morganti, P. Bionanotechnology to Save the Environment. Plant and Fishery's Biomass as Alternative to Petrol; MDPI: Basel, Switzerland, 2019; pp. 1-21.

(C) 2020 by the authors. Licensee MDPI, Basel, Switzerland. This article is an open access article distributed under the terms and conditions of the Creative Commons Attribution (CC BY) license (http://creativecommons.org/licenses/by/4.0/). 